\author{
Gábor CSANÁDI \\ Adrienne CSIZMADY \\ Gergely OLT
}

\title{
Recent trends in urban renewal in Budapest
}

This article outlines recent social processes in central $\mathrm{Bu}$ dapest, focusing on social sustainability and gentrification, and presents the potential social conflicts emerging in this area. We examine the recent history of the housing market and areas of gentrification in the city centre. The second part of the article presents the trends and possible long-term effects of real-estate development in the research area. The article concludes that the gentrification events in central Budapest could be a warning signal of future social displacement and social exclusion.

Key words: social sustainability, urban renewal, gentrification, city centres, housing market 


\section{Introduction}

Modern concepts of "sustainability" seek to integrate other fields of research in addition to the relation between nature and people. There are ongoing debates about the criteria of sustainability among the representatives of very different applied ideas and theoretical principles. These include strong and interesting arguments, but the common element is that most of them use normative approaches. Although we do not reject these initiatives, this article's point of view differs from them. Our goal is not to show the "right" or "best" practices for urban renewal that lead to sustainability according to particular criteria. Instead, we examine the social conflicts emerging in a city (or neighbourhood) and then draw lessons from these to determine how the social aspects of sustainability apply in practice.

\section{Sustainable city centres}

According to the basic documents of sustainable development Our Common Future (also known as the Brundtland Report; see World commission on environment and development, 1987) and the Convention on Biological Diversity (also known as the Rio Treaty; see United nations, 1992) - the different goals on the path to sustainability are equally important and supposed to be achieved only together. The most attention is devoted to the topic of environmental sustainability (McKenzie, 2004; Littig \& Greißler, 2005; Lee, 2006). One-pillar models generally focus on environmental sustainability, and social and economic aspects are subordinated to environmental goals..$^{[1]}$ Three-pillar models seek to be more general than the strictly environmental approach and appear to be more acceptable in discourse about sustainability. It is equally important for the three pillars of environmental, economic and social sustainability to be preserved for the benefit of future generations. In addition to environmental and economic needs, cultural and social values are also represented among future generations' needs, as mentioned in the definition in the Brundtland Report.

Not surprisingly, this model has received substantial criticism, principally because of the choice of these three particular pillars. In addition to these aspects, the aesthetic, cultural, religious, spiritual, political and constitutional aspects should be taken into account (Pfahl, 2005).

In practice, environmental and economic sustainability pushes the third pillar into the background. On the one hand, economics and the environment could be connected well by arguments for cost-efficient solutions; on the other hand, ecological and economic arguments seem to draw more public attention than social questions (Littig \& Greißler, 2005). Furthermore, the environmental and economical questions seem to be more operationalisable (Omann \& Spangenberg, 2002).

The three (or more) pillars of sustainability are closely interrelated. The ways they affect each other have not yet been fully studied. However, a sustainable community does not mean only a community (e.g., a city) that functions properly without a constant need for outside support or action by the government. The various components of sustainability always have an effect on one another. For example, interactions between people and nature fundamentally influence development (Littig \& Greißler, 2005).

Many different opinions exist among researchers regarding social sustainability. One could almost say that each individual study has a unique point of view, and it is hard to even define what "social" means. This paper does not seek to clarify all questions in the discourse on sustainability. In fact, it only tries to present a point of view concentrating on social sustainability: the relation between gentrification and sustainability. To this end, we examine the processes that took place in central Budapest after the fall of communism. Some of these could indicate the start of gentrification or make gentrification possible in the future.

\subsection{A socially sustainable city centre}

Whereas the theoretical framework of social sustainability has not yet fully evolved, there are practical examples of socially sustainable cities. In the research project conducted by UNESCO MOST, ten large cities were compared in terms of governance, culture, infrastructure, housing, transport and employment. Considering the results, not only governmental policies but also local agendas seem to be important factors in achieving sustainable communities. The authors summarise their findings as follows: social sustainability is "development and/or growth that is compatible with the harmonious evolution of civil society, fostering an environment conducive to the compatible cohabitation of culturally and socially diverse groups while at the same time encouraging social integration, with improvements in the quality of life for all segments of the population" (Polése \& Stren, 2000: 14).

Questions of social sustainability are closely related to those concerning changes in the city centre. Gentrification has effects on almost every factor mentioned in the discourse about social sustainability. Of course, these are not only negative effects, such as shrinking the public space available to lower-income residents. According to several observers, incoming higher-status residents are better able to articulate and defend the interests of the neighbourhood and assist economic development, which could also benefit the poorer residents in the area. Looking at 
the problem from a citywide perspective, gentrification has the potential to generate a social mix rather than another form of extreme segregation. It could be a step forward for sustainability as defined previously: it reduces (local) environmental pollution when compared to suburbanisation, explicit spatial segregation and the concentration of the urban poor. There are examples of city centres in which there were signs of gentrification, but the results of renewal seem to be closer to the "ideal" of a sustainable city than the former situation with an urban slum and sterile suburban idyll.

We have to mention here that some researchers, based on recent and older findings, strongly deny any positive effects of gentrification. Their concerns about social mixing as a government agenda are summarized, for example, in Loretta Lees (2008). Others state that through adequate government initiatives gentrification could be a means of sustainable urban renewal in terms of all three pillars, if it means the movement of new residents to empty, unused urban spaces (Hamnett, 2003). To present the entire discourse about gentrification is beyond the scope of our article. For an insightful analysis into recent discussions on this topic, see Claire Colomb (2007).

The reasons for gentrification are still being debated. Here we use a summary of the literature by Gary Bridge (2001). Some researchers think the roots of this process lie in the accumulation of capital and the revaluation of real estate in the city centre. Some of these areas became less valuable during deindustrialisation, and an ever-widening gap emerged between the market value and potential value of central locations. This gap between market and potential value can be narrowed by the residential renewal of city centres or, in other words, by gentrification (Smith, 1979, 1987). With this approach, if the movement of capital is explained, all the other processes become explainable.

Other research suggests that cultural changes are the most important factors in gentrification. These assume that more highly educated middle-class consumers have demands that they can satisfy only in the city centre and not in the characterless malls and hypermarkets of the suburbs (Ley, 1980, 1986).

Some explanations attribute a central role to the changes in proportions among employment sectors. The ever-increasing importance of the tertiary sector has resulted in residential areas having to become closer to city centre workplaces. A central location is vital for most service industries (Hamnett, 1991).

The growing number of female employees has affected the number of single and two-person households, and the city centre seems more appropriate for their different lifestyles and demands (Bondi, 1991). The phenomenon of marginal gentrification has resulted in a growing number of single-parent households in the city centre (mostly women and their children), where they have a better chance of finding the amenities needed for their lifestyle than in homogeneous suburbs (Rose, 1984).

The fact that the cost of renewals and refurbishments have been decreasing because of technical development (Redfern, 1997) could also be an important factor.

Gentrification can be seen in many cities throughout the wor$\mathrm{ld}$, and in many cases it resembles colonial-era enclaves that were segregated from other areas of the city. Gentrification is a global process. Because of the expansion of multinational companies, their employees have become residents in various cities all around the globe with the same demands for consumption and amenities that are typical in western city centres. A new service class has emerged in these cities to satisfy their needs (Sassen, 2000). These processes are forming neighbourhoods in city centres worldwide, making them like the colonial enclaves of global capitalism (Atkinson \& Bridge, 2005).

Finally, we can summarise all of this by referring to Chris Hamnett's (1991) opinion that a theory explaining gentrification should answer the questions where (in the sense of geographical place and neighbourhood), who (the people involved in the process and why) and when (why that period of time).

For gentrification to emerge, it is important that some typical features of the urban environment be present. For example, the urban environment should create cultural values that make the area desirable for social groups dissatisfied with the suburban way of life. It is also important to have certain groups of people (potential city-centre residents) with a particular mindset that find the opportunities of city centres preferable to other forms of residence. This habitus cannot incorporate fear of heterogeneity, fear of the unknown, and a desire for complete safety and control over the environment. Some theorists of gentrification assume that the social groups meeting these criteria are "producible" and that their numbers are growing (Hamnett, 1991; Smith, 2005).[2]

Of course, this balance of environmental supply and demand of new residents is rarely realised, perhaps only in the first wave of gentrification, where most of the newcomers are young professionals, artists and students. As soon as living in the city centre becomes fashionable and venture capital sees an opportunity, newcomers become people that buy things simply because they can (Lees, 2003). This could turn heterogeneous neighbourhoods into islands of complete social segregation. This process often changes the architectural design of the area by building brutal enclosed fortresses for the rich. It can also 
change the use of space in the area and make the signs of social problems vanish by force. The result is an empty, boring, nonliving urban space.

\section{Gentrification in central Budapest}

In this paper, "central Budapest" refers to parts of districts VI, VII, VIII and IX (all of them on the Pest side of the city), where most of the residential dwellings were constructed at the end of the nineteenth and beginning of the twentieth century and show the traditional architectural design of Pest (Figure 1).

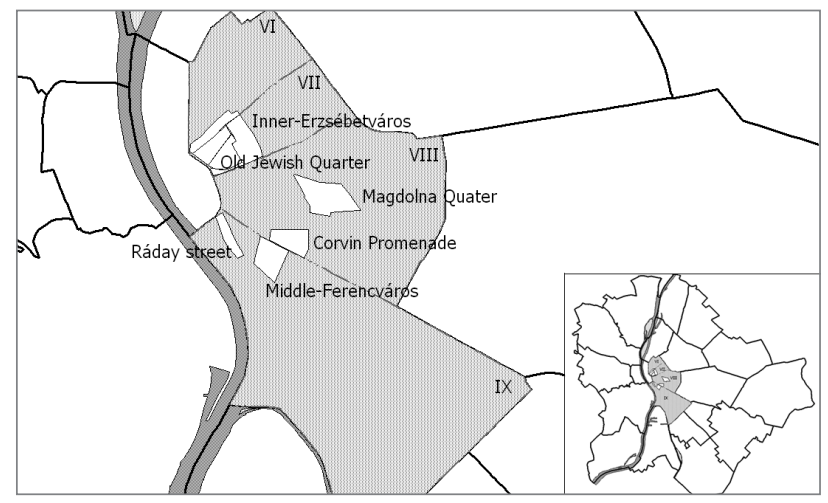

Note: VI, VII, VIII, IX = district number.

Figure 1: Maps of the city centre (illustration: Gábor Csanádi, Adrienne Csizmady, Gergely Olt).

Unfortunately, there are no up-to-date census data available that clearly show signs of gentrification. Nonetheless, there are neighbourhoods where signs of the process can be detected. In addition, we are able to use the results of our representative survey ${ }^{[3]}$ conducted in a specific part of the city centre (the inner part of District VII, or Erzsébetváros).

First we examined the history of the area of possible gentrification in Budapest. This part of the city was almost untouched until the collapse of communism. The most important features of the built environment were slow deterioration and decay. (Only a few urban-renovation pilot projects were carried out, limited to some blocks of flats, without any spill-over effects.) Because of the economic decline in the early 1990s, no significant changes were seen for a long time. The most important factors of the renewal were private residential developments started around 2000 and the increasing number of these projects until recently. This process was not limited to vacant sites; by using the loopholes in regulations, in many cases this was accomplished by demolishing old buildings. The rise of the real-estate industry was caused by the growing measure of solvent demand. This process was primarily facilitated by cheap subsidised loans for new homeowners. After the era of cheap loans ended and the global crisis struck in 2008, city-centre building projects became very limited again. Even so, these seven years after 2000 resulted in significant micro-level changes in some neighbourhoods that still have important consequences for questions of sustainability as well. Now we present the most important factors in our research area. The first of these should be the issues of ownership of dwellings and building demolition and construction.

Renovation and refurbishment are closely related to ownership structure. The dwellings in the city centre became privatised at an overwhelming rate. (In most cases, the families that were living in the flat became the new owners.) This represented the end of the rental market in the city centre. Large-scale renovation projects could only start in neighbourhoods where the local council maintained ownership of the dwellings. This phenomenon occurred in the central part of District IX, which was declared a reconstruction area ${ }^{[4]}$ before privatisation, and so ownership remained in the hands of the local council. The other two areas that must be mentioned here are the (since demolished) neighbourhood of the Corvin Promenade project and the social reconstruction area of the Magdolna Quarter, both in District VIII. In these cases, the local government owned a much larger proportion of the flats than in other parts of the city centre.

Whereas the building projects before 2000 mainly used empty sites, later the fast-paced demolition of the city centre began. Buildings that could have been saved and renovated became the casualties of developers' and local council officers' interests. Examining the data between 2001 and 2006, the yearly averages of the indicator "number of demolished dwellings per hundred newly built dwellings" (calculated by the Hungarian Central Statistical Office) show the following numbers: approximately eight in District VI, twelve in District VII, eight in District VIII and six in District IX. In addition, the demolished dwellings were often not those in the worst condition or without bathrooms.

The demolitions were followed by construction: Between 2002 and 2007 ten to sixteen times more dwellings were built in districts VI and VII than in the previous years. There was a smaller but also significant change in District IX, where this number is 3.5, and in District VIII, where the number of newly built dwellings was 2.5 times more than before. Most of these flats were built for sale. ${ }^{[5]}$

Table 1: Number of new dwellings, 2001-2007.

\begin{tabular}{llllllll}
\hline District & 2001 & 2002 & 2003 & 2004 & 2005 & 2006 & 2007 \\
\hline VI & 5 & 51 & 31 & 43 & 269 & 219 & 73 \\
\hline VII & 44 & 54 & 49 & 204 & 434 & 222 & 273 \\
\hline VIII & 84 & 247 & 199 & 512 & 259 & 315 & 331 \\
\hline IX & 504 & 653 & 625 & 987 & 1008 & 663 & 1065
\end{tabular}

Source: Hungarian Central Statistical Office (2008). 
The developers, most of whom were Spanish and Israeli, were looking for sites to build large projects sometimes containing several hundred units, and the results of these combined with the former appearance and use of the street were often very disparate. In addition, whereas the return-on-investment calculations of real-estate developers and demand were already pushing the market towards smaller dwellings, ${ }^{[6]}$ the average size of the flats in this area was even smaller $\left(47\right.$ to $\left.59 \mathrm{~m}^{2}\right)$. Researchers and analysts dealing with this topic had had concerns for a long time about the long-term negative effects caused by small flats. The common interests of developers with less capital and buyers with limited spending capacity contributed to the lack of change in the trends.

Because of the growth of developer interest since 2003, there was a rise in real-estate value in central Pest, which constitutes a good basis for gentrification. Alongside residential developments, new office buildings emerged, and this could be a step towards the working, functioning city described by Alex Marshall. In his view, a city is a place where revenue is created, profit is made and capital accumulates. The city works, creates jobs and attracts "immigrants" (Marshall, 2000). Naturally the amount of capital invested in the given area and the quality of buildings and flats are important factors in the renewal process of the district or neighbourhood. These factors can also affect who finds this part of the city attractive.

This could be a tool in the hands of developers for influencing the future of a neighbourhood because they consider which social groups will be attracted to the area when they determine their prices. For example, the prices of the large new projects in the Old Jewish Quarter of Pest were set higher than those for old dwellings in the area. The developers believed that their future clients would also have faith in the rising realestate prices in the quarter, and so there would be customers looking for luxury in a run-down neighbourhood in the city centre. At this point, the economic crisis had a strong effect on this process, investments stopped and the transformation of the quarter - which was having important social effects faltered. One of the most important projects, Gozsdu Court, was finished almost exactly when the first wave of the crisis occurred. The sale of overpriced flats and retail spaces progressed slowly. Because of the typical size and the central location of the dwellings, it is easy to imagine the clients the developer anticipated: foreigners or a segment of younger clients that found it important to have a new, "clean" and above all safe flat. (These notions often came up in our interviews, especially with people moving to Budapest from the countryside.) They wanted to see the neighbourhood as a place where the run-down environment (which is due to be cleaned up) is compensated for by the advantages of the central location. This decaying but still fascinating area with buildings from the late ninete- enth and early twentieth century was attractive and repulsive at the same time. The prices of the flats were almost twice those of others in a similar neighbourhood. As a result, most of the new owners (foreigners and locals) bought their flats as speculators, many flats remained unsold and therefore only a few people actually moved in. Currently Gozsdu Court is a desolate, empty, abandoned place. It is clean, but perhaps too clean, and maybe this is why it is spiritless. The project had an important effect, but not in the sense that it contributed to a higher quality of the area. Quite the opposite: it created an environment that cannot be integrated into the old one but is unviable on its own.

The future of another quarter in District VIII also depends completely on developers. The Corvin Promenade project ${ }^{[7]}$ resulted in the demolition of many residential blocks of flats. The building project started in a large empty area and the overall image of the quarter is changing. Nineteenth-century classicist houses have been replaced by modern twenty-firstcentury designs, which are similar to the housing estates in terms of density and height. In addition to the flats, 150,000 $\mathrm{m}^{2}$ of office space and commercial outlets will be built. A city is being constructed within the city centre that operates under its own laws, and the question remains how this will affect the broader neighbourhood. Will it be an enclosed or segregated area where people arrive by car to avoid the surrounding slum? Will it have a positive spill-over effect on its environment and will prices rise because of this (so that the current residents lose ground after a while and the social characteristics of the area change completely)? Today both scenarios seem possible.

All of these changes (demolitions, building projects and renovation efforts) set the real-estate market in motion, and in the six years between 2002 and 2008 there were rising real-estate prices in central Pest. Large-scale renovation projects or simply expectations about them raised prices most significantly. In the Old Jewish Quarter, the rise has been about $40 \%$ and it reflects the temporary success of demolition. There are many signs showing that this rise in real-estate value will be short lived. On the one hand, these prices were calculated on an overheated real-estate market. On the other hand, the quality of buildings is often insufficient and the new residents are expecting not only high-status flats, but a flourishing life in the city centre as well. The new sterile environment has a very different milieu and perhaps it is less attractive than the heterogeneous colourful old one.

The biggest increase in prices occurred in District VIII. In the Magdolna Quarter, this was 129\%, and it was not much lower in the Corvin Promenade project. This increase must have been caused by speculation and a general increase in prices, and not by the actual effects of renovation. 
The changes in the real-estate market in the city centre had numerous effects on the area. On the one hand, many dwellings were developed, the market took off and the area became important for a particular segment of homebuyers. The most important motivation for them was to have a newly built flat, and their presence could even make the environment more attractive. On the other hand, because of subsidised loans, many people decided to buy a flat instead of renting. (The monthly instalments were often the same as the monthly rent for a similar flat.) Quite a few university students or young employees (often moving to the city from the countryside) chose a first flat to start their independent lives in this area. The third reason was the available cheap low-cost dwellings, known as "small flats" (26 to $\left.35 \mathrm{~m}^{2}\right)$. The long-term negative effects of this process can already be seen, and the lack of larger flats will be a problem in the future. On the other hand, it could be a short-term advantage for students because they can find flats available in the city centre close to their university. This process could lead to studentification of the city centre (Smith, 2005).

As mentioned earlier, the new trend of events was strongly influenced by the crisis. The demand generated by foreigners decreased in the city centre last year (for the newly built flats in districts VII-IX). In District VIII, real-estate prices rose more slowly than building costs, so it was not worth starting new projects. Finally, developers were planning smaller, 100to 150-unit projects instead of 200- to 400-unit ones, so they were also looking for smaller building sites. (Urban planners find this change a good sign, although they still claim that even these smaller projects are too large for an area that is already densely populated.) The economic crisis had a negative effect on the market (and, naturally, developers recognised this as a problem); on the other hand, it at least temporarily stopped demolition. There is a chance that for at least a few years fewer old houses will be demolished in the city centre, and perhaps during the years of the economic crisis the views and approaches of the officials and politicians involved in urban planning will change. Perhaps in the long term this could result in more careful maintenance of built cultural heritage in the city centre.
After examining the real-estate market, we discuss the situation of residents in the area. Our main question is whether there is a certain part of the city that can be called a gentrified neighbourhood. In general, according to statistical data and other sources of data (e.g., surveys, local council databases, case studies, etc.), there is currently no large-scale, radical gentrification in our research area. However, at the same time the slowdown of population loss is a clear sign of the beginning of gentrification. During the 1990s, the population loss was significant: by 2001 in districts VI and VII the fall was about 25.8 to $22.6 \%$, in District IX $19.7 \%$ and in District VIII $11.5 \%$. After 2001, the decline became slower and the data from 2007 show only a few percent (2 to 5\%) loss (whereas the average in Budapest was 4.6\%).

The case of District VII is the most interesting in this respect because the natural decrease was higher here than in other parts of the city centre, but the new residents moving in counterbalanced this, so the population loss was only $3.3 \%$. The first sign of gentrification is visible here: the population of the run-down area is still decreasing, but it is balanced by the new occupants. Our survey data show that during recent (i.e., pre-economic crisis) years the influx was substantial.

However, according to the changes in population dynamics we can only presume gentrification because these data cannot show the social status changes in the area. Nonetheless, according to our 2010 survey, in the last eight years the proportion of more highly educated residents grew further and the share of less-educated residents decreased in the Jewish Quarter. It is even more important that the proportion of higher-status groups among the newcomers is growing and the share of lowstatus strata is decreasing. The two sets of data shown in Tables 3 and 4 together show that the population change accelerated in the last period and that the status of newcomers is higher than that of the population moving out. This could be a first sign of gentrification because in gentrification literature one of the most important status indicators is the proportion of residents with a higher education (see Atkinson, 2000; Seo, 2002).

Table 2: Population changes in central districts, 2001-2007.

\begin{tabular}{lllll}
\hline District & $\begin{array}{l}2001 \\
\text { population }\end{array}$ & $\begin{array}{l}2007 \\
\text { population }\end{array}$ & $\begin{array}{l}2001 \text { population } \% \\
(1990=100 \%)\end{array}$ & $\begin{array}{l}2007 \text { population \% } \\
(2001=100 \%)\end{array}$ \\
\hline VI & 44,141 & 41,839 & 74.2 & 94.8 \\
\hline VII & 64,141 & 62,001 & 77.4 & 96.7 \\
\hline VIII & 81,791 & 80,166 & 88.5 & 98.0 \\
\hline IX & 62,999 & 59,992 & 80.3 & 95.2 \\
\hline All of Budapest & $1,775,203$ & $1,696,128$ & 88.2 & 95.4 \\
\hline
\end{tabular}

Source: Hungarian Central Statistical Office (2007). 
Table 3: Distribution of residents by birth or moving-in period, 2010.

\begin{tabular}{ll}
\hline Born or moved in & $\%$ \\
\hline $1916-1969$ & 25.6 \\
\hline $1970-1989$ & 22.1 \\
\hline $1990-2001$ & 19.9 \\
\hline $2002-2005$ & 9.1 \\
\hline $2006-2010$ & 23.3 \\
\hline Total & 100.0 \\
\hline$N$ & 1,541
\end{tabular}

Source: authors' survey, 2010.

The changes in other dimensions are characteristic as well. For example, the age structure is shifting to the younger strata. Although the population of this part of the city is still older than in others, the rate of the elderly decreased moderately within the research area, and strongly outside the Boulevard. Among young adults, the share of twenty- to thirty-year-olds is exceptionally high around Mikszáth Square and along Ráday Street. Both areas were subject to public spatial renovation and this could indicate the success of these initiatives from a certain aspect. These facts could be a sign of gentrification or studentification. The Jewish Quarter, with its central location and relatively low prices, is very similar to these places. The cheaper flats close to Semmelweis University could also be places for students. Currently it is typical for some students to share a large flat in this neighbourhood between Illés Street and Korányi Street. The thirty- to forty-year-old group is more typical in the central part of District IX (Ferencváros) because it was only here that the sizes of flats were suitable for raising children.

After the collapse of communism, higher-status residents of the city centre moved to the suburbs of Budapest and there were no significant renovation efforts to prevent suburbanisation. Nonetheless, there were micro-level changes that could indicate a potential increase in real-estate value in the city centre. This offers the potential to improve the physical environment of the area and change the social composition of the population. The demolitions and new projects typically did not affect the most run-down and lowest social-status areas of these four districts of central Pest. The neighbourhoods that were renovated had a social potential for a different type of renovation.
Although assisting the most helpless and vulnerable is cited as an important goal of renovation, the designated areas, the agents behind the projects and the methods applied are all inconsistent with this goal. The motivation behind such activity is not improvement of the situation, but changes on the real-estate market. The relative economic boom around 2000 made the city centre more attractive to developers ${ }^{[8]}$ and not completely independently from this - more desirable for various middle- and higher-status social groups.

\section{Conclusion}

Many factors affect gentrification. Ornate buildings dating from the beginning of the twentieth century and the special milieu of Budapest's courtyards are consistent with the aesthetics of gentrification (Jager, 1986; Zukin, 1987). The architecture of the buildings is adaptable for flourishing business activities and the service industry in the ground floors of properties. The streets are narrow with a certain run-down charm and romantic atmosphere. Some neighbourhoods have even seen the arrival of artists with their own projects (the Boulevard and Brezsnyev Gallery) or initiatives with more funding and a more commercial approach (the VAM Design Centre). The first long-term alternative project also emerged in this area (the Sirály Café).

There is also a significant risk in the situation. The real-estate scandals of District VII (the mayor of the district is currently in custody and facing fraud and corruption charges) is reminiscent of the rent-gap theory, in which owners leave their buildings to their own devices, speculating on a turn in the market. The potential real-estate value of the Jewish Quarter became so high (before the crisis) that the best way to make a profit seemed to be to build hotels, and a significant proportion of the residents wanted to move away because of the uncertain situation (Csanádi et al., 2006). The latest trends in the office market (increasingly more office space is being built on the outskirts) are weakening the supply-side pressure for gentrification. If the function of the city centre disappears, the area may lose all hope because there would be no reason for the middle class to move into the city centre close to their workplace.

Table 4: Level of education in the survey area, 2001 and 2010.

\begin{tabular}{lllll}
\hline Highest level of education & 2001 & 2010 & Incomers, 2002-2005 & Incomers, 2006-2010 \\
\hline Primary & 38.1 & 30.3 & 26.5 & 17.3 \\
\hline Secondary & 39.2 & 37.8 & 36.4 & 44.1 \\
\hline Tertiary & 22.7 & 32.0 & 37.1 & 38.6 \\
\hline Total & 100.0 & 100.0 & 100.0 & 100.0 \\
\hline$N$ & 18,101 & 1,539 & 140 & 359 \\
\hline
\end{tabular}

Source: Hungarian Central Statistical Office, 2001; authors' survey, 2010. 
Our research and other studies indicate that the reason gentrification is not an even stronger phenomenon in Budapest is the relatively low level of demand. In the post-communist economy, lack of capital and poverty affected a considerable portion of society. Social differences became large and there is no robust middle class. Among these circumstances, there is a need for strong reflection on social status: having one's own detached house and the attitude "my house is my castle" are important tools for this. The new suburban way of life could remain more exclusive for these social groups. This was also facilitated by the system of real-estate subsidies, which prefers newly built dwellings, and real-estate projects are also easier to carry out in greenfield projects than in the bustling city centre. It looks as though Hungarian society does not have enough of the "new middle class" described in the gentrification literature. Nonetheless, there are signs of gentrification and some conditions for it are present, but the relative lack of potential gentrifiers has prevented the quick development of this process for a while (Hamnett, 1991).

International examples show that there are various strategies for encouraging some social groups to move to the city centre. The renovation process had similar effects in Budapest, but only in very limited areas. However, during the last few years before the economic crisis, foreign real-estate development was substantial in some areas and most of the empty houses and building sites are now in the hands of private developers. This could mean that a change in economic trends in the future could generate radical changes in central Pest.

From the viewpoint of sustainability, the most important question in this process (although not fully examined in this article) is its effect on the lower-status groups that were present in the gentrified areas. In some cases, moving away from their neighbourhood is desirable for them as well. Because of the constant uncertainty in the renovation process and the fear that they have to leave their home, many of the residents postponed refurbishments and now they feel trapped in their own social housing. It seems impossible to sell or trade these flats. Many residents only want to move into a less insecure situation (Csanádi et al., 2007). For policy-makers, the "de-concentration of poverty" often seems to be good idea in the form of exporting it to other parts of the city, or to the countryside. The well-known policy is to buy cheap houses or apartments in the outskirts or in poor villages. The result is new concentration in less-developed areas (described in Ladányi, 2008; Csanádi et al., 2010). On the other hand, these social groups are the most vulnerable and powerless ones in the articulation of their interests, so the question of price remains: do these social groups have to pay for renovation that was carried out to benefit higher-status social groups?
Moving to the city centre can be an alternative for a particular segment of the middle class. They can find a better quality of life there, and force the renovation of the neighbourhood. Nonetheless segregation - sometimes in other parts of the city or in the countryside - becomes stronger, and the falling living standards of the lower status groups could be a high price to pay for a more vibrant and liveable city centre.

\section{Gábor Csanádi \\ Eötvös Loránd University of Budapest, Faculty of Social Sciences, Centre for Urban and Regional Research, Budapest, Hungary E-mail: gcsanadi@tatk.elte.hu \\ Adrienne Csizmady \\ Eötvös Loránd University of Budapest, Faculty of Social Sciences, Centre for Urban and Regional Research, Budapest, Hungary \\ Gergely Olt \\ Eötvös Loránd University of Budapest, Faculty of Social Sciences, Centre for Urban and Regional Research, Budapest, Hungary}

\section{Notes}

${ }^{[1]}$ If the public uproar because of pollution affects politicians, they usually react with the most simplistic environmental regulations.

[2] The term "studentification" refers to the occupation of central areas by university students in Britain. It could make the urban way of life normal and satisfactory for some of those that experienced it. A higher level of education could represent different cultural and consumer needs, and perhaps a different habitus towards the typical city problems mentioned above.

${ }^{[3]}$ We conducted a representative survey concerning social changes in the inner part of District VII (Erzsébetváros). The total sample size was 1,585 .

${ }^{[4]}$ In Budapest it was only District IX (Ferencváros) that enforced its right and prohibited the sale of real estate in a renovation area. Because of this and in spite of strong pressure by the residents, 7,300 dwellings remained banned from sale.

${ }^{[5]}$ Developer interest was highest in District VIII (30 projects), followed by District IX (20 buildings), District VII (19 project) and District VI (10 projects).

[6] In 2000 the average flat size was $102 \mathrm{~m}^{2}$, in 2004 it was $71 \mathrm{~m}^{2}$ and in 2007 it was only $54 \mathrm{~m}^{2}$.

[7] The area bordered by the Corvin Cinema, Práter Street, Szigony Street and Üllői Avenue.

${ }^{[8]}$ Developers were able to defend their interests not only at the local level, but also at higher levels.

\section{References}

Atkinson, R. (2000) Measuring gentrification and displacement in greater London. Urban Studies, 37(1), pp. 149-166.

Atkinson, R. \& Bridge, G. (2005) Introduction. In: Atkinson, R. \& 
Bridge G. (eds.) Gentrification in a global context: The new urban colonialism, pp. 1-17. London, Routledge.

Bondi, L. (1991) Gender divisions and gentrification: A critique. Transactions of the Institutions of the British Geographers, 16(2), pp. 290-298.

Bridge, G. (2001) Bourdieu, rational action and the time-space strategy of gentrification. Transactions of the Institute of British Geographers, 26(2), pp. 205-216.

Colomb, C. (2007) Unpacking new labour's "urban renaissance" agenda: Towards a socially sustainable reurbanization of British cities? Planning, Practice \& Research, 22(1), pp. 1-24.

Csanádi, G., Csizmady, A., Kőszeghy, L. \& Tomay, K. (2006) Belső-erzsébetvárosi rehabilitáció. Tér és Társadalom, 20(1), pp. 73-92.

Csanádi, G., Csizmady, A., Kőszeghy, L. \& Tomay, K. (2007) A városrehabilitáció társadalmi hatásai Budapesten. In: Enyedi, G. (eds.) A történelmi városközpontok átalakulásának hatásai. pp. 93-118. Budapest, MTA Társadalomkutató Központ.

Csanádi, G., Csizmady, A., Kocsis, J., Kőszeghy, L. \& Tomay, K. (2010) Város-tervező-társadalom. Budapest, Sik Kiadó.

Hamnett, C. (1991) The blind man and the elephant: The explanation of gentrification. Transactions of the Institute of British Geographers, 16(2), pp. 173-189.

Hamnett, C. (2003) Unequal city: London in the global arena. London, Routledge.

Hungarian Central Statistical Office (2001) Népszámlálás 2001. Budapest.

Hungarian Central Statistical Office (2007) Társadalmi, gazdasági jellemzők. Budapest.

Hungarian Central Statistical Office (2008) Lakásstatisztikai Évkönyvek 2001-2007. Budapest.

Jager, M. (1986) Class definition and the aesthetics of gentrification: Victoriana in Melbourne. In: Smith, N. \& Williams, P. (eds.) Gentrification of the city, pp. 78-91. Boston, Allan and Unwin.

Ladányi, J. (2008) Lakóhelyi szegregáció Budapesten, Budapest, Új mandátum Kiadó.

Lee, K. N. (2006) Urban sustainability and the limits of classical environmentalism. Environment and Urbanization, 18(1), pp. 9-22.

Lees, L. (2003) Super-gentrification: The case of Brooklyn Heights, New York City. Urban Studies, 40(12), pp. 2487-2510.

Lees, L. (2008) Gentrification and social mixing: Towards an inclusive urban renaissance? Urban Studies, 45(12), pp. 24-49.

Ley, D. (1980) Liberal ideology and the post-industrial city. Annals of the Association of American Geographers, 70, pp. 238-258.

Ley, D. (1986) Alternative explanations for inner city gentrification: A Canadian assessment. Annals of the Association of American Geographers 76, pp. $521-535$.

Littig, B. \& Greißler, E. (2005) Social sustainability: A catchword between political pragmatism and social theory. International Journal of Sustainable Development, 8(1-2), pp. 65-79.

Marshall, A. (2000) How cities work: Suburbs, sprawl, and the roads not taken. Austin, University of Texas Press.
McKenzie, S. (2004) Social sustainability: Towards some definitions. (= Hawke Research Institute Working Paper Series 27). Magill, SA, University of South Australia.

Omann, I. \& Spangenberg, J. H. (2002) Assessing social sustainability: The social dimension of sustainability in a socio-economic scenario. Paper presented at the 7th Biennial Conference of the International Society for Ecological Economics, 6-9 March, Sousse, Tunisia. Typescript.

Pfahl, S. (2005) Institutional sustainability. International Journal of Sustainable Development, 8(1-2), pp. 80-96.

Polése, M. \& Stren R. (eds.) (2000) The social sustainability of cities: Diversity and the management of change. Toronto, University of Toronto Press.

Redfern, P. (1997) A new look at gentrification: Gentrification and domestic technologies. Environment and Planning, 29(7), pp. $1275-1296$.

Rose, D. (1984) Rethinking of gentrification beyond the uneven development of Marxist and urban theory. Environment and Planning, D: Society and Space, 2(1), pp. 47-74.

Sassen, S. (2000) Cities in a world economy. Thousand Oaks, CA, Pine Forge Press.

Seo, J. K. (2002) Re-urbanisation in regenerated areas of Manchester and Glasgow: New residents and the problem of sustainability. Cities, 19(2), pp. 113-121.

Smith, D. P. (2005) Studentification the gentrification factory? In: Atkinson, R. \& Bridge, G. (eds.) Gentrification in a global context: The new urban colonialism. London, Routledge.

Smith, N. (1979) A theory of gentrification: A back to the city movement by capital not people. Journal of the American Planning Association, 45(4), pp. 538-548.

Smith, N. (1987) Gentrification and the rent gap. Annals of the Association of American Geographers, 77, pp. 462-478.

United Nations (1992) Convention on biological diversity. Rio de Janeiro.

World Commission on Environment and Development (1997) Our common future. Oxford, Oxford University Press.

Zukin, S. (1987) Gentrification culture and capital in the urban core. Annual Review of Sociology, 13, pp. 129-147. 